\title{
Constructivist Learning Theory and Logopedagogy in Arts Education
}

\author{
Miroslav D. Drljača \\ University of Banja Luka, Faculty of Philosophy, Teacher's study programme
}

\section{Abstract}

The research referenced in this paper falls into the categories of qualitative, empirical, non-experimental action research, as well as ethnographic and artbased research. The target population consists of students enrolled in senior years of primary school and students of general secondary schools (gymnasiums). The research sample included 425 primary school and gymnasium students, and the empirical research put emphasis on qualitative methods and data collection through systematic observation, interviews and content analysis of student art projects.

Since arts education in school is inherently creative, it is marked by significant characteristics of constructivism. Classes of this kind seek to overcome the shortcomings of minimal hours through the benefits of collaborative learning, project-based learning $(P B L)$, research-based learning ( $R B L)$ and action learning, as well as other methodological strategies. In order for students to take a stand towards their own learning and assume responsibility for it, they must recognise meaning in what they are learning and creating. This is why it is necessary to enrich the teaching methods currently used in arts education with the digital media accessible to students. In this paper, constructivism and logopedagogy are considered as particular approaches to learning and arts education. The findings

of this empirical research show that arts education can be significantly improved and made more interesting for students by relying on logotherapeutic principles and logopedagogical methods.

Key words: action research; arts education; extracurricular activities; project-based education; social networks 


\section{Introduction}

Students in today's schools are often not interested in their lessons; they easily lose concentration, find their classes monotonous and boring, and have no opportunity to share opinions or put forward ideas. Unfortunately, much of this also applies to arts education in primary schools and gymnasiums (Drljača, 2018). Even though a lot of research shows that art classes are loved by students (Kuščević et al., 2009; Drljača, 2018), they still come under the strong influence of the teaching and learning that values reproduction of what is taught or observed and does not encourage divergent thinking. Artistic creation and other activities related to works of fine art enable students to become aware of their visual experiences and open up opportunities for them to form an artistic point of view and a critical attitude towards their surroundings (Duh et al., 2012). This validates the student opinion that school is a crucial factor in encouraging young people's artistic inclinations, which indicates that schools have a great responsibility in terms of instructing and educating students in the field of visual arts (Kuščević et al., 2009).

Students enrolled in compulsory primary education spend approximately 900 hours per year at school; in secondary school, more specifically, gymnasiums, this equals 1,000 hours or more. This begs the question of whether the time spent in school is optimally used, especially when it comes to subjects that are allocated only one contact hour per week, such as arts and music education. This implies that it is important to establish not only what students have learned and by what means, but also what knowledge, competencies, habits and skills they have acquired. Many students take part in extracurricular activities, such as clubs, courses, sports and the like, but the time spent on these activities is not included in the total school hours. In addition to deciding how to optimise time management and teaching methods, it is also important to determine to what extent the education system is capable of meeting young people's needs, as they spend most of their time in school. The question remains whether we have moved away from the system whose failings were documented in the early 20th century by creators of reform pedagogy and the many alternative schools and, if so, how far (Matijević \& Topolovčan, 2018).

Today, young people exist in two realities, one that is taught at school and another one which exists outside of school. The former often exposes them to the kind of content they do not always deem applicable or pertinent to their lives, and the point of which they cannot see while studying. The latter is filled with aggressive content that is presented to young people on the Internet and through television programmes as something to emulate in their own conduct. Exposing young people to seemingly successful individuals and their lifestyles can twist their perception of reality because they do not realise that the image of success that is served to us by the media is often just a way of compensating for the lack of meaning in those people's personal lives (Lowen, 2012). Young people are faced with the challenge and responsibility of consolidating 
those two realities and discovering a third one, which, unlike the previous two, will reveal to them the goal and purpose behind learning and existence. This paper seeks to demonstrate that schools need to develop meaningful lesson content because educational systems that do not present their students with creative tasks can be a cause of spiritual collapse, leading to the dampening and withering of a student's spirit (Berđajev, 2007). In this paper, constructivism and logopedagogy are considered as particular scientific ways of approaching learning and arts education, while keeping in mind that the constructivist learning theory, logotherapy and logopedagogy promote the same values, such as independent student work, creation of a stimulating environment and the importance of goal setting and discovering meaning. The aim here is to present the results of a round of empirical research that demonstrates how important it is for the depth and intensity of student participation and engagement in arts classes for students to be given tasks that align with their interests, allow them the freedom to make their own choices and encourage them to take a stand and assume responsibility for their work. Likewise, these results also illustrate the importance of making school work fun and pleasurable for students. Project-based learning shows that students enjoy independent research and that they make inferences and draw conclusions in a variety of ways. Additionally, the objective of this paper is to show the extent to which the method of paradoxical intention can affect fear and prejudices of individual students. By presenting the links between the constructivist learning theory and logotherapy one can deduce a variety of benefits to implementing the aforementioned theories in arts education.

Based on the author's own experience and the analysis of several studies related to arts education conducted in primary schools and gymnasiums, the conclusion is that it is possible to find solutions for certain problems by employing logotherapeutic teaching methods, as backed by research (Drljača, 2018). Only some possible links between logotherapy and constructivism are presented in this paper. This is followed by the results of empirical and action research, as well as descriptions of actual lessons in which the logotherapeutic method of paradoxical intention was applied.

\section{Logotherapy and the constructivist learning theory: theoretical perspectives}

Logotherapy, also known as therapy through meaning, was founded by Viktor Frankl in the 1930s. Next to Freud's psychoanalysis and Adler's individual psychology, it has been dubbed by many the third Viennese school of psychotherapy. The logotherapeutic concept of a human being is based on three tenets: freedom of will, will to meaning and meaning in life (Frankl, 2016, p. 28). Frankl notes that a time of plenty and an abundance of choice can lead one to experience existential frustration, or meaninglessness of one's existence (Frankl, 2011). In a time when people's will to meaning is increasingly frustrated, they are overcome by a sense of meaninglessness, which is often coupled with a sense of emptiness. Frankl describes it as an "existential vacuum", which mainly 
manifests itself as boredom and apathy. In this context, boredom is indicative of the loss of interest in the world, and apathy implies a lack of initiative to do or change something in the world (Frankl, 2001). Symptomatology of the existential vacuum is defined by the neurotic triad that includes depression, aggression and addiction. These feelings can bring one into a state of noogenic neurosis, which Frankl believes is caused by the fact young people are no longer led by instincts but rely on reason instead, and have broken with tradition, so they no longer know what they ought to do. Instead, they do what others do, turning into conformists, or what others tell them to do, which results in totalitarianism (Frankl, 2014).

According to Frankl, the main question each person should ask themselves, which often arises precisely in moments of futility and apathy, is that of the meaning of life. In addition to finding the true meaning of life, or what Frankl calls "ultimate" or "supra-meaning" (Frankl, 2011), one is also faced with the challenge of finding meaning in everyday life, which is something that cannot be invented but must rather be discovered. In this way, one becomes an active co-creator of one's own life, free but responsible, able to make decisions independently while taking a stand toward the limitations of personal freedom. One ought to respond personally and independently to every situation, which in fact means taking responsibility for one's own life (Nikić, 2003). Thus, logotherapy is considered not only a form of treatment but also a way of rectifying a patient's attitude toward his or her inescapable fate (Frankl, 2016. p. 17). Frankl classifies values into three categories, as creative, experiential and attitudinal values. This set reflects the three main ways in which people can discover the meaning of life. The first value concerns that which we give back to the world, as our creation, by doing or creating something; the second value consists of that which we take from the world through our interactions with others and experience, that is, through what we experience; the third value represents our attitude towards our own suffering when facing a fate that cannot be altered. According to Frankl, logotherapy is characterised as intentional and focused on the future. Thus, Frankl suggested that his patients should not look at their inner turmoil, but turn their eyes towards what is yet to come. $\mathrm{He}$ said it is not what pulls us down that counts, but rather that which awaits us in the future and still needs to be realised (Frankl, 2016).

For Frankl, freedom does not mean being free from biological, psychological and sociological conditions. It is, really, freedom for something, and not freedom from something (Puljić, 2005). According to Frankl's teachings, man is a free, responsible, undetermined being, guided by conscience toward finding meaning. Conscience is considered the meaning organ and can be defined as the intuitive capacity of man to find out the meaning of a situation (Frankl, 2016). Frankl believes our strongest motivation is not for finding ourselves, but for finding meaning external to us, which includes "forgetting" and rising above ourselves, transcending our ego and focusing on someone or something beyond us. Self-transcendence is understood as the fundamental fact that being human is always being in relation to something or someone other 
than oneself, be it a meaning to fulfil, or a human being we are awaiting. If this selftranscendent quality is missing, then one's very existence faces uncertainty and sinks to lows. On the other hand, owing to self-transcendence, we are able to forget about ourselves, give ourselves to others and make sense of our existence (Frankl, 2014).

Viktor Frankl's theory stands in opposition to theories that claim that the main goal of human motivation is self-realisation. According to Frankl, if self-realisation were our main goal and motivation for life, we would find ourselves trapped in a "closed system" and we would not have positive interactions with other people and the outside world. In differentiating between higher and lower needs, Maslow never took it into account that even when lower needs are not satisfied, a higher need, such as the will to meaning, may become very pronounced. The need for meaning is independent of all other needs; thus, it cannot be reduced to or derived from any other needs (Frankl, 2014).

Viktor Frankl sought to introduce spirituality to psychotherapy, seeing it as an area significantly different and independent from the psychological in the strictest sense of the word, which necessitated that the spiritual be introduced into the unconscious, exactly in the form of the spiritual unconscious (Frankl, 2011). The spiritual dimension is one of the three dimensions accepted by Frankl, who differentiates between the physical, mental and spiritual dimensions in human beings (Pahljina 2011,p. 273). That is why, from Frankl's point of view, the word "logos" means both "meaning" and "spirit", but again, with no primarily religious connotations. Here, "logos" refers to the humanity of human beings, in addition to the meaning of being human (Frankl, 2016, p. 29).

In practice, logotherapy uses the methods of paradoxical intention and dereflection. Paradoxical intention is used in therapy instead of pathogenically forced intention, and dereflection is the corrective used to replace pathogenic hyper-reflection (see more: Frankl, 2011, p. 50). According to Frankl (1978), a certain degree of tension is a prerequisite for mental health. This is tension between what one has already achieved and what one still needs to accomplish, or the gap between what one is and what one is yet to become. Such a tension is inherent to human beings and as such it indispensable for our well-being. That is why, according to logotherapists, it is wrong to think that one needs homoeostasis to be mentally healthy. According to Frankl, one does not need homeostasis, but rather noo-dynamics, or a spiritual dynamics of polar tension, with one pole representing the meaning one is yet to fulfil, and the other by the actual person that needs to fulfil it. Humans enjoy a certain measure of tension. They find pleasure in challenges, for example, in competitions and sport, where tension increases the level of excitement. An increase in excitement leads to pleasure, whereas a decrease in pleasure leads to boredom or depression. Conclusively, the goal of life is not a static equilibrium; rather, life includes the phenomena of growth and creativity (Lowen, 2012).

The theory of didactic constructivism is based on the works of Dewey, Montessori, Kolb, Piaget and Vygotsky. According to the constructivist theory of learning and 
teaching, the experience that an individual gains through contact with his or her environment and the objects within it is given the highest importance (Matijević, 2017). When it comes to constructivist didactics, important works include Vygotsky 1983; Burner, 1974, 2000; Piaget, 1979, 1986; Watzlawick, 1984; and others. Even though there are many types of constructivism, they all consider learning to be an active process that takes place through discovery and creation, during which students are given the liberty to do their own research within the given framework or structures. In this process, the student has freedom, while the teacher's role is to act as his or her students' guide and to create an environment conducive to learning. Therefore, constructivists believe that every person constructs new meanings in learning situations that they are actively involved in, based on what they see, hear, speak, do, explore and discover (Matijević, 2013, p. 3). Thus, for the proponents of radical constructivism, knowledge is by no means a copy of reality (Glasersfeld, 1995a and 1995b), whereas social constructivism teaches that knowledge is constructed through social and environmental interactions, and not through one's own cognition. Students discover basic rules and principles through independent activities, while the role of the teacher is to create problem-solving tasks that encourage students to ask questions, explore and experiment (Bruner, 1974). Constructivist teachers should, among other things, encourage and accept student autonomy and initiative, and use cognitive terminology such as "classify", "analyse", "predict", and "create". They should make decisions on the spot according to student responses, seek understanding based on previous experiences and encourage different forms of communication (Brooks \& Brooks, 1993). By analysing the markers of constructivism and scientific research of the brain, authors Maras, Topolovčan and Matijević (2018) point to the importance of factors such as student activity, social interaction, positive emotions, stress reduction, stimulating environment, individual and social construction of one's own knowledge, values-based and cultural determination, holistic approach to development, physical activity, reflection and practical work in educational processes.

Since education is the foundation of every democratic society, it is something that every individual should take part in, according to their own abilities. At the same time, the educator should understand each child in terms of their specific inclinations, needs and preferences (Dewey, 2004). Constructivists endorse classrooms with more learning and less teaching, where knowledge cannot be taught or transmitted (Matijević, 2017). The most important thing in such classrooms is determining the roles and positions of the teacher and the student. By acknowledging and encouraging the development of different types of intelligence in students (Gardner, 1983), teachers use different methods and strategies to teach, such as collaborative learning, learning through play, action research, problem-based learning and project-based education.

According to Velički and Velički, the precautionary use of the term logotherapy in education is preferred over logopedagogy, in order to avoid possible misinterpretations and the false assumption that the term refers to a branch of pedagogy. In addition, 
the word "therapy" should not be taken to mean medical treatment only, but rather to encompass everything implied by its etymology, which represents one of the basic premises of logotherapy. These authors also claim that logopedagogy cannot be limited to pedagogical work and activities in the strictest sense of the word, but that it should be expanded to include pedagogues in the broadest sense, that is, to encompass educators, lecturers, teachers, professors and anyone practically involved in teaching and education, those who apply elements of logotherapy in any kind of pedagogical activity, i.e. in their work with children and youths. A prerequisite for this would be personal competence in the field of logotherapy and existential analysis, as well as proficiency in the philosophical and psychotherapeutic approach founded and developed by Viktor Frankl (Velički \& Velički, 2018, p. 338).

Problems that are present in all walks of life also seriously impact on a most important sphere, that of young people's education. In its struggle for better life, society has secured material wealth, but it has started to lose its humanity. A person surrounded by abundance is trapped in boredom and indifference and undertakes no initiative for change (Frankl, 2001). Existential frustration manifests itself mainly as boredom and apathy, which has become a challenge both in education and psychiatry. Educational systems should equip people with means to find meaning in life; on the contrary, education frequently contributes to the existential vacuum (Frankl, 2016). School is an institution that should give its attention to proper values so that everyone involved in its activities, naturally, including students, can discover and assimilate them into their own value system (Koschina, 2012). In order for children to develop to their full potential, their existence and the obstacles they encounter in life must have meaning to them (Frankl, 2010). We are told that arts give us pleasure, but nobody tells us why this is and why it is useful to us. It is important to understand that art can be used as a tool to tackle problems in life (Arnheim, 2008). Contemporary arts education is increasingly used worldwide as a bridge between artistic expression and diversity, uniqueness, illness, etc. (Herzog \& Serec, 2016, p. 232). As proactive and creative beings, humans reshape nature with their activity and become constructive beings to the extent to which they manage to realise their human potential. Knowledge enhances social inclusion and active personal growth, but also competitiveness, which is really important in the current context of globalisation (Jukić, 2013, p. 26).

\section{Similarities between logotherapy and the constructivist learning theory}

In the text that follows, we will show some similarities between logotherapy and the constructivist learning theory, such as the idea that knowledge and meaning can be discovered through one's activity; the importance of a supportive environment for a student or patient; the teacher-student and therapist-patient relationship; the application of maieutics and paradoxical intention; facing fear; the role of humour in learning and therapy; the importance of communication for learning and healing; 
personal freedom and accountability; the importance of being challenged; a holistic approach to being human; goal setting; and a focus on the future.

According to constructivists, the learner is the constructor of his or her own knowledge, which cannot be passively received from someone else, but must be actively sought out and built up through one's own actions. Similarly, according to Viktor Frankl (2011), meaning cannot be given as a recipe and patients must seek it out on their own. Meaning is an independent constant, a belief that is also held by Viktor Frankl's followers and his student Lukas (2006), who claims that meaning is unique for every human, and that it is absolute and unconnected to any other condition of life. According to Frankl (2014), instincts are transmitted via genes and values via traditions, whereas meaning is a matter of personal discovery because it is unique. Every person must find it for themselves; it must be discovered through one's own means, and as such, that discovery will always have a unique meaning.

A discussion of an encouraging school environment commands that we determine and analyse the roles of both the teacher and student in the classroom. Constructivists believe that if teachers choose just one teaching style (e.g. frontal teaching, collaborative learning, inquiry-based learning, etc.), they are unable to fully engage their students' abilities (Brooks \& Brooks, 1993). In addition to teaching styles, the teacher must also understand the inclinations, needs and preferences of each child (Dewey, 2004). As well as that, the teacher should create problem-solving situations that stimulate students, make them ask questions, do research and experiment (Bruner, 1974). Learning must be encouraged by external factors, though not just by listening to the teacher talk, but also through the creation of challenging and stimulating situations and scenarios that invite the student to take part and react critically, instead of just watching and listening passively (Matijević, 2013). In order for competencies to be successfully transferred in the learning process, both the student and teacher must be active partners in the conversation related to the task at hand (Topolovčan et al., 2017, p. 54). According to Frankl, no logotherapeutic dialogue is predetermined and should instead always be completely open to moving in "countless" directions. Frankl's logotherapy does not place importance upon technique, but rather upon the human relationship between the doctor and patient, which is considered to be a personal and existential encounter because logotherapy does simply not concern itself with ontos, or being, but also with logos, or meaning (Frankl, 2016; Škodlar, 2016). By seeking out the origins of constructivist methods of learning and teaching, as well as logotherapeutical methods, we find ourselves in ancient times, looking at maieutics, the Socratic mode of enquiry (Topolovčan et al., 2017). Just like Socrates' disciples were guided to understanding through carefully thought-out questions, a logotherapist also doesn't ask just anything, but poses only such questions that are likely to entice therapeutic and meaningfully correspondent answers that will encourage the patient to move closer to existential change in attitude through self-formation and self-education (Lukas, 2006). According to logotherapists, the more a person is focused on pleasure, 
the more likely they are to miss their goal. Therefore, paradoxical intention is offered as a quick treatment for patients with phobic and obsessive-compulsive disorders. Encouraging patient to try and do or wish to experience precisely what they fear leads to the inversion of intentions (Frankl, 2016). Likewise, the student and teacher obtain knowledge through dialogue, where the teacher does not have a pre-prepared truth for the student, as it is "born" from the interaction. Frankl feigns ignorance and pushes his interlocutors to the extreme, i.e., he forces them to see the absurdity of their convictions; regardless of their attempts to make them seem logical, he leads them to discover potential prejudices and presumptions in what they considered to be (perfectly) substantiated claims (Štengl, 2005). Štengl further says that Socratic irony and maieutics can be applied successfully both in logotherapy and education. Here, the teacher feigns ignorance before students and asks sensible questions, meant to lead them to insights that may as well be misconceptions. In such a system, students draw their own conclusions with the help of the teacher, tearing down their old beliefs and attitudes, and building new ones instead.

At this point, it is important to mention Frankl's hyper-intention and hyper-reflection, i.e. forced intention coupled with excessive attention to oneself (Frankl, 2016). Hyperreflection can be the very reason why students fail at learning. Therefore, if a teacher notices that a student is hyperfixating, it is important to apply Frankl's method of dereflection in the classroom, and the preferred ways to do this is by employing the maieutic method and the method of paradoxical intention. Teachers who follow the principles of constructivist teaching methods use student feedback to make decisions about their own behaviour, choice of teaching strategies, and activities and learning content "on the spot"; such teachers stimulate critical thinking and inquisitiveness in the classroom, demand that students frame their questions in a thoughtful and openended manner, and encourage them to ask each other questions; they pose leading questions of their own and demand that students explain their answers; they put them in situations meant to bring into question their preconceptions, induce them to spot contradictions and stimulate debate (see more: Brooks \& Brooks, 1993).

In order for us to function normally, it is very important that we face our fears and develop strategies to resolve the problems caused by those fears. Frankl (1978) talks about two types of fear: realistic fears and neurotic fears. A realistic fear is, for example, the fear of death, whereas a neurotic fear is, for example, agoraphobia. The former cannot be tranquilised away by its psychodynamic interpretation, whereas the latter cannot be cured with the help of philosophical understanding. Being a type of therapy that involves healing with meaning, logotherapy has developed an action technique. Anticipatory anxiety, which is a condition that is often seen in neurotics, is used as the starting point. This kind of anxiety typically creates the exact reaction that the patient fears (Frankl, 1978, p. 102). Logotherapy also teaches that "fear of fear" also causes "flight from fear", and that phobias are developed when pathological avoidance patterns of behaviour are established. Frankl saw paradoxical intention as a solution in 
such cases and documented a variety of examples, all of which came from his patients' letters (Frankl, 2014, p. 110). Our fears and anxieties are not important per se; it is our attitude to them - which Frankl sees as a matter of free will - that makes a difference (Frankl, 2014). These examples from logotherapy can have implications for teaching when it comes to dispelling fear in students, which is usually caused by fear of failure (examples and images 1 and 2).

Humour plays an important role both in logotherapy and education, as discussed by Matijević in Humour in Education, where he quotes Viktor Frankl's experiences and theory (see more: Matijević, 1994, p. 9). Humour and heroism point to the uniquely human capacity for self-detachment. Because of this ability, we cannot simply distance ourselves from a specific situation, but we also detach ourselves from ourselves and are able to choose our attitude to our self (Frankl, 2016). Because of self-detachment, humans are capable of making jokes at their expense, laughing at themselves and mocking their own fears (Frankl, 2014). Humour affords us the ability to place phenomena in perspective and distance ourselves from whatever we may be faced with (Frankl, 2016). Additionally, a certain dose of humour is crucial in education, especially in classes that require dissenting opinions, because creativity implies divergent thinking, offering multiple answers to a question, expressing emotions and humour, and alleviating boredom and fear (Dubovicki \& Omićević, 2016, p. 106).

Constructivists place a particular emphasis on the importance of communication and the child's social interaction with its surroundings. For many authors, knowledge is a direct result of an individual interacting with his or her social environment (Glasersfeld, 1995a and 1995b; Piaget, 1979; Vygotsky, 1975, 1983; Reeve, 2010; Brković, 2011). In his writings, Piaget (1979) emphasises the importance of socialisation for children and adolescents, singling out peer cooperation in situations such as playing because, according to him, play has an important role in the moral development of a child. For Piaget, a child represents an active being that impacts on the surrounding world through assimilation and accommodation, and develops through interaction with it. Likewise, Vygotsky (1983) also emphasises the importance of sign systems that originated from the human need for communication. Frankl (1978) remarks that the true meaning of life must be discovered in the world rather than within man and his own psyche, claiming that man is not a closed system. Therefore, the true goal of life cannot consist only of self-actualisation, because human existence is, essentially, all about self-transcendence.

Human freedom is freedom within limits. Humans are not exempt from conditions that are set for them, but they are free to adopt an attitude to them; they do not condition us absolutely. It is up to us whether he succumb to them and surrender (Frankl, 2014). Glasser (2005) believes that external stimuli are not the cause of our actions. We only receive information from our external environment, but our reactions to this information depend on us. Hence, the information that students receive from their teacher and the way in which they receive it are extremely important. Nevertheless, it is students 
who decide on the level of importance. Rousseau (1989) also believed that students should not be given rules, but rather become accustomed to discovering them on their own. For example, activities in arts education represent a form of creative effort where students are expected to react in an uninhibited, spontaneous and unrestrained manner (Herceg et al., 2010). Montessori (2013a) says that young people must have enough freedom to act on their own initiatives. However, for an individual action to be both uninhibited and useful, it must be limited within a certain framework and operate within a set of rules that represent a necessary guide. Any given rules must apply to the whole community and not just individual members. Additionally, only essential rules - those that are sufficient enough to ensure order and enable progress - should be given. The greater students' freedom of choice, the higher their intrinsic motivation (Pattal et al., 2010). Frankl believes that in addition to being free, man is also a responsible and existential being (Frankl, 2011). According to him, freedom is the negative aspect of this phenomenon, accountability the positive one (Frankl, 2014). Freedom is always in danger of degenerating into mere arbitrariness unless it is lived in terms of accountability (Frankl, 2016). One can only truly respond to "life issues" with activity, and this is done by everyone taking responsibility for their own existence (Frankl, 2011). Human superiority comes from the possibility of becoming guilty and having the responsibility to overcome guilt (Frankl, 2016). The same goes for constructivist learning, where students are not only active, but also responsible for the construction of their knowledge (Mušanović, 2000).

If an individual is not presented with the challenge of completing a task and is thus spared from the special kind of tension caused by such a task, this may result in a certain type of neurosis called "noogenic" neurosis (Frankl, 2014). Poljak (1965) points to the importance of measuring the efforts required from students through their participation in designed class activities. If students are faced with what they deem an easy challenge, they will not find it interesting or approach its completion in the right way. Giving student tasks that are too difficult and beyond their ability to solve will have a similar outcome. Classroom activities such as collaborative learning are not challenging only for students, but also for scientists (Gentry et al., 2001). We can thus understand tension as the driving force that pushes a person to keep searching in the zone of proximal development. The zone of proximal development has a more direct effect on the dynamics of intellectual development and success than a person's current level (Vygotsky, 1983). By overcoming both the personal and social zone of current development, creative individuals move within the zone of general proximal development (Šefer, 2000).

Viktor Frankl's theory is characterised by a holistic approach to humans. According to him, we are not one-dimensional, but have a physical, psychological and spiritual dimension. As such, we engage with others and are predestined to search for meaning (Puljić, 2005). Frankl (1997) defines a human being as a unity in spite of multiplicity. He also says that the process of searching for meaning comes down to holistic observation 
(Frankl, 2011). This means that the very complexity that defines humans and sets them apart from other beings justifies the fact that logotherapy is multifaceted and may described as philosophical, medical, pedagogical, psychotherapeutic, pastoral and so on, all for the purpose of guiding us toward finding personal meaning in ourselves in the best possible manner. The most accurate way of defining logotherapy is to consider it the "missing link" between all the pieces of the puzzle, which is made up of the different branches of humanities, and as such, representing a truly comprehensive synopsis of man and his claim on the world (Lukas, 2006, p.7). Maria Montessori (2013) wonders what good there is in transferring knowledge if we disregard the overall development. Jukić (2013) believes that a holistic approach is a prerequisite for the development of all knowledge and the survival of humans and society in general.

Identity does not result from one's concentration on one's self, but rather from dedication to a cause, from finding one's self through the fulfilment of what is particularly one's work (Frankl, 2016, p. 139). Adler (1999) believes that spiritual life can develop only if a goal has been set beforehand. According to Adler, goals are set in such a way that their achievement holds promise of feeling a sense of superiority or of reaching heights where one feels life is worth living. Lowen (2012) believes that goal setting is a creative process and that those who dedicate their life to a higher purpose can find happiness. According to Frankl's concept of logotherapy (Frankl, 2016), man lives with intention, i.e. with a goal. This goal is to attribute meaning to life; we as individuals aspire to create values. Moreover, we are essentially and inherently driven to creativity and values. The idea that people have the capacity to delay immediate gratification or tolerate pain in order to gain greater satisfaction in the future (Lowen, 2012) is in line with Frankl's theory that we neglect basic needs in order to achieve goals (Frankl, 1978).

Being human means existing within a dynamic of polar tension between reality and the ideal that has yet to be materialised (Frankl, 2016). Furthermore, Frankl maintains that man does not care for pleasure or happiness, but rather wants that which exerts them as effects; thus, he advises his patients to focus on what awaits them in the future (Frankl, 2016). Constructivist learning is also future-oriented - it is anticipatory in that it forms the basis for mastering the skill of learning how to learn (Topolovčan et al., 2017, p. 65). Constructivists advocate innovative learning and emphasise the importance of anticipation and prediction over passive adaptation to existing circumstances, as well as active participation of the learning subject. Anticipatory learning implies activating one's fantasy and creativity and taking into account developmental aspirations and values. The opposite concept of "innovative" learning is adaptive learning (Matijević, 2013). Similarly, Watson (2011) says that all efforts in life must be future-oriented and that even though constant worry about the future redoubles these efforts, it also makes them easier and more fruitful.

After presenting some of the links between the constructivist learning theory and logotherapy and analysing their characteristics in greater detail, we can conclude that 
it is justified to connect these two doctrines and draw comparisons between them. In addition, we maintain that it is necessary to continue searching for and establishing links between these two theories and their application because of their potential for education in general, and for arts education in particular.

\section{Methods used in the empirical and qualitative research}

The research referenced in this paper belongs to qualitative, empirical, nonexperimental and action research, as well as ethnographic and art-based research. Project-based learning includes teaching methods such as group work, action-based learning methods, collaborative teamwork and cooperative learning. The data needed for analysis and scientific interpretation was collected through systematic observation, introspection, surveys, interviews and selected case studies. The emphasis, therefore, is on qualitative methods as the research approach. The class during which we applied the method of paradoxical intention also included other action-based methods, such as asking leading questions and case studies.

One objective of this paper is to present the links between the ideas of constructivism and the theories of logotherapy, and to show how they can be implemented in arts education. We sought to justify this approach with the results of empirical and action research that is presented in this paper. The second objective is to show how exactly the method of paradoxical intention can have a positive effect on student motivation and make their work more creative. In accordance with the above objectives, the following research questions were posed:

Is it possible to establish a link between the constructivist learning theory and theories of logotherapy?

To what extent can the constructivist learning theory and logotherapy enhance learning and teaching in the context of arts education?

How can the method of paradoxical intention be used, and what are its benefits in arts education?

The empirical research sample included 425 students, of whom 227 (53.41\%) were year-nine primary school students, and 198 (46.59\%) year-two gymnasium students. Fifty-eight students participated in the project week, of whom 29 primary school students and 29 gymnasium students. Art projects created by two gymnasium students of different ages as a result of the method of paradoxical intention were used in the drawing analysis.

\section{Research results that point to the importance of applying logotherapeutic and constructivist methods in arts education}

The results of the empirical and action research presented in this paper show that if applied in the classroom, logotherapy and logopedagogy could have a very positive effect on the quality of arts education. The goal was to analyse student activity in art 
classes with year-nine primary school students and year-two gymnasium students, and also to organise and analyse a student action research project, both in primary and secondary school, with the aim of exposing students to work with colours (Drljača, 2018). In this paper, we also present the results of application of the method of paradoxical intention in the classroom.

For the purposes of this paper, it should be of interest to present and illustrate the factors of interest, choice, fun and social promotion, and challenge as featured in the survey used to analyse student activity in art classes.

Students like working on tasks that they find interesting and engaging. Also, it was noticed they like participating in different research projects, having freedom in their work, doing independent research and setting clear goals. The factor of choice indicates that it is important to allow students to choose independently who they wish to work with, techniques, materials, and the tasks and projects they wish to work on. When students are given more alternatives to choose from, their intrinsic motivation increases (Pattal et al., 2010). The students said they can have fun in the art class, choose the audience they wish to present their completed projects to, and establish communication among each other, all of which are factors that have a positive effect on student motivation. According to Lowen (2012), happiness and fun fall into the category of transcendent experiences. The physical experience of pleasure is transferred onto the product, which reflects the pleasure that one takes in being good at what one does. Glasser (2005) states that few people realise that fun is a basic human need. It is important to ensure that students find the tasks and projects set in the art class challenging enough, and that they can use challenging materials and books.

During the project research week, the students were required to learn about colours and how they influence people, and how much they and the people around them really know about colours. Each day of the week was dedicated to a certain colour; for the duration of the project, the students wore clothing items of specific colours, chose food according to colour, did online research for various colour-related content, interviewed the people they came in contact with, and took part in other similar activities. Student communication/interaction was of particular importance for the project; beside introspection, the students spent quite some time interviewing the people around them. They paid attention to the use of colours in architecture, communication, the understanding of art, getting to know people through colours, colour combinations in fashion, interior design, design, photography, etc. During the exit forum, the students underlined the importance of communication. They felt like they had learned a lot by interviewing students at their school and other people. They also spoke of the importance of using the Internet in their research, especially Facebook, which allowed them to supplement their findings in a variety of ways and to establish communication with their mentor, which was especially relevant when it came to keeping their research diaries and documenting their findings. Project-based arts education indicates greater student motivation, the development of social skills 
and confidence, active participation in the teaching process, and more permanent and greater-quality acquisition of knowledge, skills and attitudes (Tomljenović \& Novaković, 2012). Making works of art and participating in other activities related to fine arts help students become more aware of their visual experiences and adopt an artistic point of view and a critical attitude to their surroundings (Duh et al., 2012). Projectbased teaching activities require a cross-curricular, thematic approach, which provides students with different affinities and abilities with more opportunities. Arts education includes a range of interconnecting themes, which also correlate with themes from other subjects. If a student fails to meet the requirements in one area, it is necessary to find a way to help him or her compensate for this in another. This approach prevents students from becoming discouraged and instead motivates them to stay committed and be more active in art classes (Hanson, 2002; Imonikege, 2013; Lorimer, 2011).

Fears and previously formed prejudices are problems teachers often encounter in the classroom. Teachers face a great challenge in helping frightened students relax and stimulating them to do the work required of them. An even greater challenge is attempting to make students realise their deeply held conviction they have no talent for applied art is basically a misconception. Usually, such students are not motivated to put in effort, both in the case of school in general and when it comes to individual subjects. Many talented children go unnoticed because of misconceptions of this kind. Jung (2015) rightly said the matter of gifted children is by no means a simple one, as scholastic aptitude and achievement are sometimes not indicative of talent. In fact, it can be the opposite, with children performing poorly because of distractions and petty details. Such children are often seen as lazy, negligent, careless, restless, stubborn, and even drowsy. One can attempt to find a solution for problems like these in the application of logotherapeutic techniques. In this case, the application of paradoxical intention for logotherapeutic purposes can prove particularly useful. If a student exhibits excessive hyper-intention and hyper-reflection, the teacher ought to utilise the method of dereflection (Frankl, 2016), which involves ignoring oneself (Frankl, 2007). To reverse intentions, students should be motivated and guided to do exactly what they are afraid of (Frankl, 2016).

What follows is two examples of use of the logotherapeutic method of paradoxical intention with students in art classes. The first example (Figure 1) shows a drawing made by a year-one gymnasium student, who used to avoid most of her school obligations due to a hand injury. Not only did she refuse to write, but she also reached a point where she completely neglected all school-related work. Whenever she needed to write or draw, she offered the excuse of not being able to write with her left hand and of her right hand being injured. She refused both to dictate to other students and to respond orally. During an art lesson, it was suggested that she should use her left hand. At first, she protested, saying she couldn't even write with her left hand, let alone draw. After that, she was asked to try and make a "bad" drawing with her left hand, one that would lack any aesthetic quality, which she would not receive a mark for. She 
approached the task with no great expectations; however, the longer she worked, and the more she heard her drawing was actually good, the more excited and amazed by her ability she became. Visibly pleased, the student completed the drawing (Figure 1), got the highest mark, and no longer had any issues with drawing in the art class. Her attitude towards the subject also changed for the better.

The second example (Figure 2) shows the project of a year-two gymnasium student who previously refused to participate in the art class. He used to say he could only study history and theory of art, but had no talent for drawing, which was something he had been told as far back as primary school. There was no use in trying to convince him that everyone had some talent and that it needed to be nurtured and developed. $\mathrm{He}$ was particularly affected by the "good" works created by his peers. He used to say that he could never draw like that, so he shouldn't even try. An attempt was made to help the student by applying the technique of paradoxical intention. After he repeatedly claimed he had no talent and could not draw, the teacher took his statement verbatim and asked him to use his zero skills and make the worst artwork possible, so he could show everyone what a drawing made by a student who had no drawing ability looked like. After drawing the first few lines that were meant to represent still life, the student was asked by his dismayed classmates and teacher if that was what he meant when he said that he couldn't draw at all and if that was the worst he could do. After a lot of amazement, but wishing to show he could do worse, the student tried even harder. At the end of the lesson, the drawing deservedly received an excellent mark. After this, the student was exceptionally motivated in all the subsequent art lessons. His works were included in the school art exhibition, which had a profound effect on his motivation levels.

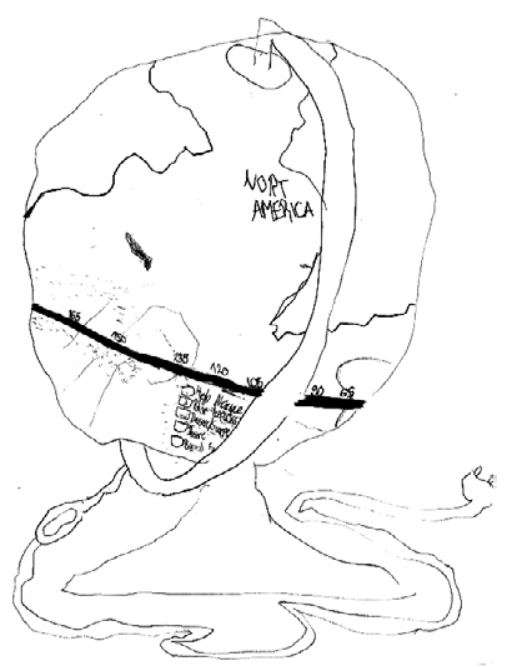

Figure 1. Globe, art project by yearone gymnasium student

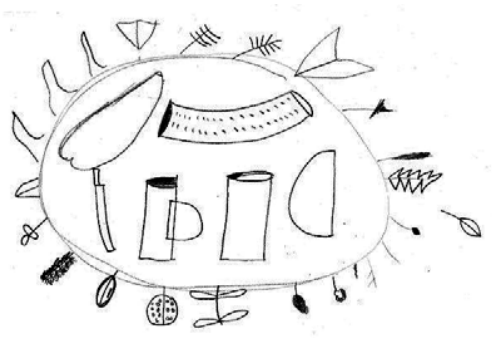

Figure 2. Still Life, art project by year-two gymnasium student 


\section{Discussion: How justified is the use of constructivist and logotherapeutic methods?}

In order to make classes interesting, teachers should not impose rules on students. Instead, they should train their ability to discover rules by themselves, so they can respond to art tasks in a spontaneous and uninhibited manner. Under such circumstances, students become the creators of their own knowledge and experiences. A comfortable learning environment is also important for a lesson to be engaging. Additionally, students will be more motivated if they can find meaning in what they do and if their work focuses on the future. The factor of choice demonstrates the significance of being able to choose. According to Frankl, man has the freedom to take a stand and make a choice, as well as assume responsibility. There can be no choice if there is no freedom. A teacher that encourages students to act independently, think for themselves and do their own research equips them with the ability to make independent choices, act, draw their own conclusions and take responsibility for themselves. Students enjoy choosing topics, materials and work partners. They like to take an active part in discussions and lesson organisation. Any kind of task will have better outcomes if one enjoys doing it and if it can be promoted in some way. Allowing students to make their own choices can remove anxiety from the creative process, especially when it comes to the fear of making mistakes. Students should be aware that the process itself is also important, and not just the end result. It is possible to have fun if one can find meaning in what one is doing, or if one clearly understands the purpose of an activity. The role of humour in therapy and learning can hardly be overrated. Arts education is as challenging as it is interesting, but this depends on how free students are to make their own choices in class and how much fun they have. We can clearly see how the four aforementioned factors (interest, choice, fun and social promotion, and challenge) interconnect here. Students are given clear, moderately challenging tasks that encourage them to enter the zone of proximal development. These tasks should be designed in a way that helps students find greater meaning in studying and doing school work, as well as give them some indication as to how the acquired skills can be used in everyday life in the future. Logotherapy and the constructivist learning theory base their teachings primarily on challenge; the challenge to act and find meaning in a process, thus making the process a goal unto itself.

The students who took part in the research project and those who participated in art class activities both highlighted the many advantages of logotherapy and constructivism, showing that arts education can truly benefit from them. In fact, project-based teaching condenses all the qualities emphasised by constructivism and Frankl's logotherapy, as it sees and approaches students and the learning process holistically. As proof of this, one need only mention student engagement, the teacher-student relationship, freedom, the challenging and stimulating environment, interaction/communication, and the other links between the two theories and practices previously mentioned in 
the paper; as well as that, there must be many more that are yet to be discovered. Both knowledge and meaning are products of one's own activity and cannot be taught or transferred. Logotherapy and constructivist education both value the student-teacher relationship over the teaching method, and here that is taken one step further, with the inclusion of student interaction with the social surroundings. Finding meaning in the world and equipping students with skills for lifelong learning are some of the key objectives of the constructivist learning theory and Frankl's logotherapy.

The cases described in the paper illustrating the use of paradoxical intention in art classes show how useful this method can be in arts education. Thanks to the method of paradoxical intention, students were able to build self-confidence and adopt a positive attitude towards the subject and school in general, which also had a big influence on the quality of their interaction with their peers. Teachers should design tasks that stimulate students and lead them to ask questions, do research and experiment. As previously stated, hyper-intention and hyper-reflection can be the reasons why some students fail. According to the principles of logotherapy, the more we focus on seeking pleasure, the more likely we are to miss our goal. Therefore, it is important to encourage patients/students to experience and face their fears. The two cases showed the importance of facing one's fears, which eventually leads to letting go of them or the prejudices previously held.

The discrete factors the empirical research focused on, the results and realisations the students had during the project week, and analysis of the art lessons and works obtained following the use of the method of paradoxical intention all indicate that there are multiple links between logopedagogy and the constructivist learning theory, as initially proposed. Our findings point to the necessity of applying the methods of the constructivist learning theory and logopedagogy in education. The presented research results are clearly very much in line with constructivism and logotherapy. Independent activity, a stimulating environment that requires assigning roles to both the student and teacher in the classroom, confronting fears, freedom and high-quality interaction, taking on challenges and setting goals, and placing a focus on the future are some of the similarities shared by constructivism and logotherapy that validate asking how much the two can advance arts education.

\section{Conclusion}

This paper presented the similarities and links shared by the theories promoted by logotherapy and constructivism. Different theorists in these two fields approach problem solving similarly. The results of the research presented herein, supported by opinions of the authors who first proposed the theories, indicate that the application of selected methods of logotherapy and the constructivist learning theory can successfully resolve problems that occur in various teaching situations. The views expressed in this paper should be taken as a starting point for further reflection on and explorations of this topic. Hence, teachers, students and parents alike should be exposed to the challenges 
and enjoy the benefits of the methods of logotherapy and the constructivist learning theory. Constructivism and logotherapy have special science-based ways of looking at education in general and arts education in particular, and allow teachers to be creative in planning their teaching strategies and solving problems. By doing so, they ensure that arts education is accepted by all students, who can grow and develop in accordance with their potential. The results presented here will hopefully serve as an illustration of how art teachers can enhance curriculum design and lesson planning and execution. Such lessons will better meet students' learning needs and keep them motivated, engaged and goal-oriented.

\section{References}

Adler, A. (1999). Poznavanje čoveka. Divit.

Arnheim, R. (2008). Novi eseji o psihologiji umjetnosti. Matica hrvatska.

Berđajev, N. (2007). Filozofija slobodnog duha. Dereta.

Brković, D. A. (2011). Razvojna psihologija. Regionalni centar za profesionalni razvoj zaposlenih u obrazovanju.

Brooks, J. G., \& Brooks, M. G. (1993). In search of understanding: The case for constructivist classrooms. Association of Supervision and Curriculum Development.

Bruner, J. (1974). Beyond the information given. George Allen \& Unwin Ltd.

Bruner, J. (2000). Kultura obrazovanja. Educa.

Dewey, J. (2004). Democracy and education. Aakar Books.

Drljača, M. (2018). Konstruktivistička nastava likovne kulture. Grafomark.

Dubovicki, S., \& Omićević, A. (2016). Nastavne metode kao poticaj učenikovoj kreativnosti. Život i škola, 62(1), 105-124.

Duh, M., Čagran, B., \& Huzjak, M. (2012). Kvaliteta i kvantiteta učenja likovne aprecijacije: Utjecaj školskih sustava na učeničku likovnu aprecijaciju. Hrvatski časopis za odgoj $i$ obrazovanje, 14(3), 625-655.

Frankl, E. V. (1978). Zašto se niste ubili: Uvod u logoterapiju. Oko tri ujutro.

Frankl, E. V. (2001). Bog kojega nismo svjesni. Biblioteka oko tri ujutro.

Frankl, E. V. (2007). Vremena odluke. UPT.

Frankl, E. V. (2011). Patnja zbog besmislena života: psihoterapija za današnje vrijeme. UPT.

Frankl, V. (2010). Život uvijek ima smisla. UPT.

Frankl, V. (2016). Kako pronaći smisao života: volja za smislom. IP “Žarko Abdulaj“.

Frankl, V. E. (2014). Nečujan vapaj za smislom. Aurum.

Gardner, H. (1983). Frames of mind : the theory of multiple intelligences. Basic Books.

Gentry, M., Gable, R. K., \& Rizza, M. G. (2002). Students' Perceptions of Classroom Activities: Are There Grade-Level and Gender Differences? Journal of Educational. Psychology, 94(3), 539-544. https://doi.org/10.1037/0022-0663.94.3.539

Glasser, W. (2005). Kvalitetna škola: Škola bez prisile. Educa. 
Hanson, J. (2002). Improving Student Learning in Mathematics and Science through the Integration of Visual Art. 77p.; Master of Arts Action Research Project, Saint Xavier University and IRI/SkyLight Professional Development Field-Based Masters Program. ED 465534.

Herceg, L., Rončević, A., \& Karlavaris, B. (2010). Metodika likovne kulture djece rane i predškolske dobi. Alfa.

Herzog, J., \& Serec, S. (2016). Likovna kultura u razrednoj nastavi s aspekta prilagođavanja učenika s poteškoćama u razvoju. Život i škola, LXII(3), 231-242.

Imonikege, M. E. (2013). Overview of the visual arts curriculum, and its relationship with evaluation and instruction. Mevlana International Journal of Education (MIJE), 3(1), $143-$ 151. https://doi.org/10.13054/mije.13.13.3.1

Jukić, R. (2013). Konstruktivizam kao poveznica poučavanja sadržaja prirodoznanstvenih i društvenih predmeta. Pedagogijska istraživanja, 10(2), 241-263.

Jung, K. G. (2015). O razvoju ličnosti. Narodna knjiga.

Koschina, E. (2012). Fundamental Values of a School. A School Policy Based on the Values of Viktor E. Frankl. European Dimension in Education and Teaching. 1 (6), 16-25.

Kuščević, D., Brajčić, M., \& Mišurac Zorica, I. (2009). Stavovi učenika osmih razreda osnovne škole o nastavnom predmetu likovna kultura. Školski vjesnik, 58(2), 189-198.

Lorimer, M. R. (2011). Arts-Infused Learning in Middle Level Classrooms. Journal for Learning through the Arts. California Lutheran University, 7(1), 1-13. https://doi.org/10.21977/ D97110003

Lowen, A. (2012). Zadovoljstvo: Kreativni pristup životu. O tempora.

Lukas E. (2006). Duhovna psihologija: Izvori smislena života. Karitativni fond UPT.

Maras, N., Topolovčan, T., \& Matijević, M. (2018). Konstruktivistička didaktika i neurodidaktika u diskursu reformne pedagogije: Teorijska polazišta, dileme i komparacija. Nova prisutnost, 16 (3), 561-577. https://doi.org/10.31192/np.16.3.9

Matijević, M. (1994). Humor u nastavi. Una-MTV.

Matijević, M. (2013). Multimedijska i konstruktivistička didaktika u učionici iz 19. stoljeća U Hrvatić, Neven i Klapan, Anita (ur.), Pedagogija i kultura. (str. 291-299). Hrvatsko pedagogijsko društvo.

Matijević, M. (2017). Na tragu didaktike nastave za net-generacije. U Matijević, M. (ur.), Nastava $i$ škola za net-generacije (str. 19 - 46). Zagreb: Učiteljski fakultet Sveučilišta u Zagrebu.

Matijević, M, \& Topolovčan, T. (2018). Izazovi i trendovi u multimedijskoj didaktici. Radovi 1, 11(2017), 87 - 99. https://doi.org/10.5937/EkoIzavov1201087N

Montesori, M. (2013). Upijajući um. MIBA Books.

Mušanović, M. (2000). Konstruktivistička teorija i obrazovni proces. U Kramar, M. (ur.), Didaktični in metodični vidiki nadaljnega razvoja izobraževanja (str. 28-35), Univerza v Mariboru, Pedagoška fakulteta Mariboru.

Nikić, M. (2003). Logoterapija i vjera u učenju Viktora E. Frankla. Nova prisutnost: časopis za intelektualna i duhovna pitanja, 1(2), 267-274.

Pahljina, C. (2011). Psihosocijalni razvoj od djetinjstva do zrele dobi Almina životna priča - studija slučaja. Napredak. 153 (2), 267 - 277. 
Pattal., A. E., Cooper, H., \& Wynn, R. S. (2010). The effectiveness and relative importance of choice in the classroom. Journal of Educational Psychology, 102(4), 896-915. https://doi. org/10.1037/a0019545

Piaget, J. (1979). Epistemologija nauka o čovjeku. Nolit.

Piaget, J., \& Inhelder, B. (1986). Intelektualni razvoj deteta. Zavod za udžbenike i nastavna sredstva.

Poljak, V. (1965). Cjelovitost nastave. Školska knjiga.

Puljić, Ž. (2005). Franklova logoterapija - liječenje smislom. Društvena istraživanja: časopis za opća društvena pitanja, 14(4-59), 78-79.

Reeve, J. (2010). Razumijevanje motivacije i emocija. Naklada Slap.

Ruso, Ž. Ž. (1989). Emil ili o vaspitanju. KUIZ "Estetika“.

Šefer, J. (2000). Kreativnost dece. Institut za pedagoška istraživanja.

Škodlar, B. (2016). Ljubav kao smisao kod psihijatrijskih bolesnika. U Pahljina, C., (ur.), Društvo nije zdravo, ali je ozdravljivo, tema, ljubav (str. 15 - 21). LOGOS.

Štengl, I. (2005). Odgajanje senzibilnosti za pitanje smisla. Doprinos misli V. E. Frankla smjernicama odgajanju. Metodički ogledi, 1(12), 25.-54.

Tomljenović, Z., \& Novaković, S. (2012). Integrated teaching project in primary school elective art classes. Metodički obzori. 7(1), 119-134. https://doi.org/10.32728/mo.07.1.2012.09

Topolovčan, T., Rajić, V., \& Matijević, M. (2017). Konstruktivistička nastava: teorija i empirijska. U H. Hrvatić, A. Klapan (ur.), Pedagogija i kultura (str. 291-299). Hrvatsko pedagogijsko društvo.

Velički, V., \& Velički, D. (2018). Logoterapija u odgoju i obrazovanju - terminološko određenje i sadržajne smjernice. Nova prisutnost. 16(2), 333 - 347.

Vigotski, L. (1975). Psihologija umetnosti. Nolit.

Vigotski, L. (1983). Mišljenje i govor. Nolit.

Von Glasersfeld, E. (1995a), A constructivist approach to teaching. In Steffe, L. P., Gale, J. (Eds.), Constructivism in Education. Lawrence Erlbaum, 3-16.

Von Glasersfeld, E. (1995b). Radical Constructivism: A Way of Knowing and Learning. Falmer.

Votson, Dž. B. (2011). Inicijativa i smelost. Život i misao.

Watzlawick, P. (1984). The Invented Reality. How Do We Know What We Believe We Know? : Contributions to Constructivism? Norton and Co.

\author{
Miroslav D. Drljača \\ Teacher's study programme \\ Faculty of Philosophy \\ University of Banja Luka \\ Bulevar vojvode Petra Bojovića 1 A, Banja Luka, Bosnia and \\ Herzegovina \\ miroslav.drljaca@ff.unibl.org
}




\section{Konstruktivistička teorija učenja i logopedagogija u nastavi likovne kulture}

\section{Sažetak}

Istraživanja na koja se pozivamo u ovom radu ubrajaju se u okvire kvalitativnih empirijskih neeksperimentalnih $i$ akcijskih istraživanja te etnografska $i$ istraživanja utemeljena na umjetnosti. Populaciju predstavljaju učenici viših razreda osnovne škole te gimnazije. Uzorak predstavlja 425 učenika osnovne škole i gimnazije, a u empirijskim istraživanjima naglasak je na kvalitativnim metodama i prikupljanju podataka sustavnim promatranjem, intervjuima i analizom sadržaja učeničkih radova.

Kako je nastava likovne kulture obilježena stvaralačkim procesom, ona ima značajne odlike konstruktivizma. Takva nastava nedostatke minimalne satnice nastoji prevladati prednostima koje nudi suradničko učenje, projektno učenje, istraživačko učenje, akcijsko učenje te druge slične metodičke strategije. Da bi učenik zauzeo stav $i$ odgovornost prema vlastitom učenju on mora prepoznati smisao u onome što uči i stvara. Zato je potrebno postojeće metodičke scenarije za nastavu likovne kulture obogatiti korištenjem digitalnih medija koje posjeduju učenici. Konstruktivizam i logopedagogiju u ovom radu razmatramo kao specifične načine gledanja na učenje i likovni odgoj. Otkrića naših empirijskih istraživanja pokazuju da se oslanjanjem na logoterapeutska načela i logopedagoške metode nastava likovne kulture može znatno unaprijediti i učiniti zanimljivijom za učenike.

Ključne riječi: akcijsko istraživanje; društvene mreže; izvannastavne aktivnosti; projektna nastava; umjetnički odgoj 